\title{
Integrated Disease Management for Root Rot of Himalayan Fir (Abies pindrow) of Western Himalayas of Kashmir, India
}

\author{
Waseem Ali Dar, P.A. Sheikh*, Baby Summuna and G.H. Dar \\ Division of Plant Pathology, S.K. University of Agricultural Sciences and Technology of \\ Kashmir, Shalimar, Srinagar-190025 Jammu and Kashmir, India \\ *Corresponding author
}

\section{A B S T R A C T}

\section{Keywords}

Antagonists, Ectomycorrhizal fungi, Fir, Root rot pathogens and integrated disease management.

\section{Article Info}

Accepted: 04 April 2017 Available Online: 10 May 2017
Root rot is one of the major problems adversely effecting the growth of fir (Abies pindrow) seedlings in Kashmir valley and the study was conducted to find out the cause of the disease. The disease was prevalent in all the three fir growing nurseries surveyed with disease incidence 32.2 and 29.3 per cent during 2013 and 2014, respectively. The pathogens associated with the disease were isolated, morphologically characterized and identified as Fusarium oxysporum f.sp. pini, Fusarium solani, Fusarium pallidoroseum, Rhizoctonia solani, Sclerotium rolfsii and Pythium sp. Fusarium oxysporum f.sp. pini was most predominant pathogen with isolation frequency of $30.0 \%$, whereas $F$. solani. $F$. pallidoroseum, R. solani, S. rolfsii and Pythium sp showed isolation frequencies of 22, 18, 12,10 and $8 \%$ respectively. All the fungi proved pathogenic and caused characteristic symptoms when inoculated separately. Among the various fungitoxicants evaluated against these pathogens during in vitro studies carbendazim and mancozeb exhibited maximum mycelial growth inhibition of 80.5 and 73.2 per cent, respectively. Various antagonists and ectomycorrhizal fungi evaluated through dual culture tests inhibited the growth of pathogens with varying degrees of inhibition. Among antagonists Trichoderma harzianum TG1 and Trichoderma viride TG2 and among the ectomycorrhizal fungi Laccaria laccata and Boletus edulis were most effective and showed mycoparasitic action and also developed zone of inhibition. During in vivo studies, fungitoxicants (carbendazim and mancozeb), antgonists (T. harzianum TG1and $T$. viride TG2) and ectomycorrhizal fungi (L. laccata and B. edulis) used individually or in combination resulted in significant reduction in root rot intensity of fir seedlings. In comparison to control treatments resulted in a significant increase in growth parameters viz., shoot and root length and in turn increased the plant biomass. Bio-agents were at par with each other in respect of plant growth when evaluated individually. Bio-agents in combination showed synergistic growth promoting action and were superior in increasing shoot and root length of inoculated fir seedlings. Fungitoxicants individually or as component of treatment combination were significantly superior to bio-agents used singly or in combination. Among the fungitoxicants, carbendazim individually or in combination was significantly superior to mancozeb in reducing the disease intensity. Among the treatments, combination of $T$. harzianum, + L. laccata + carbendazim proved significantly superior to all the treatments with respect to reduction in disease intensity and increase in growth parameters and sturdiness quotient. 


\section{Introduction}

In India 76.95 million hectares are under forests with bearing 4,498.66 million $\mathrm{m}^{3}$ total growing stock (Kiswan et al., 2009). The estimated forest area in India under conifers alone is 0.045 million $\mathrm{km}^{2}$ (Lal and Singh, 2003). As per the Forest Survey of India, forests cover in Jammu and Kashmir State is only $16,309 \mathrm{~km}^{2}$. Among these, conifers alone cover 40.87 per cent forest area (Anonymous, 2009). Conifers in Kashmir valley include Pinus wallichiana, Pinus pindrosa, Abies pindrow Cedrous deodara and Picea simthiana. They are also planted in parks and large gardens for their aesthetic value. They provide wide range of socio-economic benefits through generation of employment, forest by-products and protection of sites of cultural value and are used as fuel, herbicide, lightening pitch, shelter-belt, stuffing and timber, and also for the extraction of turpentine, tar railway sleepers and packing crackers. Its seeds contain $28.7 \%$ oil which can be exploited commercially (Luna, 1996). The conifers are mainly propagated through nursery raised seedlings. Conifers are fairly strong timber and are easy to air season and kiln dry.

Abies pindrow (Family Pinaceae) commonly known as West Himalayan Fir, occurs in North Western Himalayas at an altitude of $3000-4500 \mathrm{~m}$. Trees are $30 \mathrm{~m}$ tall or more, with a narrow pyramidal shape, bark fissured, light grey to brown, leaves spiral, $1-4 \mathrm{~cm}$ long, upper surface grooved, dark green and shiny. Male cones 1-2 cm long, axillary, ellipsoid, reddish-green; microsporophyll with two linear sporangia; microspores winged, female cones 8-12 cm long, solitary or in pairs, narrowly oblong, violetpurple; megasporophyll obovate, $2 \mathrm{~cm}$ long. Seeds 1 $1.2 \mathrm{~cm}$ long; wing twice as long as the seed. These conifers are mainly propagated through nursery raised seedlings.
As in other conifers, fir is also threatened by many root rot causing pathogens and is prone to a number of diseases both at nursery as well as at plantation level posing a serious threat to their regeneration. Roor rot problem in higher plantation is usually due to infestation of Armillaria mellae and few a Fomes species however, the nursery plantation is threatened by many soil borne pathogens viz., Pythium, Rhizoctonia, Fusarium Phytophthora and Macrophomina. These pathogens cause extensive damage to nursery plantation most of the infected seedlings fail to survive or establish after their transplantation (Douce et al., 2002). Pathogens invade terminal un-suberised roots of young seedlings, penetrate through epidermal cell wall and grow intercellularly. They decompose cell wall materials and persist by metabolising cell contents resulting in damping-off or root rot and ultimately kill the host (Garret, 1970). In view of the destructive nature of root rot pathogens, various chemical, cultural and biological strategies have been explored to reduce the effect of these pathogens (Sanjay and Kaushik, 2001; Linderman et al., 2006). Exploitation of biological agents as an alternative or complement to chemical treatment in integrated disease management strategies is widely gaining interest. As antagonistic microbes through their interaction with various soil borne plant pathogens play a vital role in maintaining microbial equilibrium and serve as powerful agents for biological diseases control. Symbionts especially mycorrhizal fungi which form integral component of fir rhizosphere are essential for growth and development of tree seedlings in soils having low nutrient content (Taylor and Alexander, 2005). Mycorrhizal root system benefits the host by increasing its root capacity to absorb nutrients from soil and also protect them from pathogenic invasion than non-mycorrhizal ones (Marx, 1969). 


\section{Materials and Methods}

\section{Survey for status of root rot of Fir}

Periodic survey for the assessment of root diseases of fir was conducted during 2013 and 2014 in the months of May, August and November in three major fir growing nurseries of Kashmir valley, viz., Seer (Anantnag) and Nangdandi (Anantnag) and Tangmarg (Baramulla). Eight plots of 1 x $2 \mathrm{~m}$ size were randomly selected in each fir nursery and root rot incidence and intensity assessed on germinated fir. Total number of seedlings and the number of seedlings infected were recorded and the percent disease incidence worked out by using the following formula:

Disease incidence $(\%)=$

$$
\frac{\text { No. of diseased plants }}{\text { Total number of plants observed }} \times 100
$$

Root rot intensity was calculated on the basis of percentage of lateral root area affected by adopting scale described by Juzwik and Rugg, (1996) with slight modifications which is as follows:

\section{Class descriptions}

$0 \quad=$ No evidence of necrotic tissues.

$1=$ Laterals with $1-20 \%$ necrotic root

2 =Laterals with $20-50 \%$ necrotic root

$3=$ Laterals with $50-75 \%$ necrotic root

4 =Laterals with more than $75 \%$ necrotic root or necrotic lesion in the whole primary root

Per cent disease intensity $=$

$$
\frac{\sum(n \times v)}{N \times G} \times 100
$$

Where,

$\Sigma=$ Summation

$\mathrm{n}=$ Number of diseased seedlings in each category

$\mathrm{v}=$ Numerical value of each category

$\mathrm{N}=$ Number of seedlings examined

$\mathrm{G}=$ Maximum grade value

Isolation, characterization and identification of pathogenic fungi

The fir seedlings with typical root rot symptoms were attempted for the isolation of associated pathogens. $5 \mathrm{~mm}$ segments of infected lateral roots were cut from these selected lateral roots at the zone of advancing decay.

The bits were surface sterilized and aseptically transferred to petri-plates containing potato dextrose agar (PDA) medium and incubated at $25 \pm 2^{\circ} \mathrm{C}$. The plates were observed regularly for mycelial growth. Outgrowing hyphal tips were subcultured to develop a purified culture (Dasgupta, 1988). The isolated fungi were studied for their colony characters, mycelial growth and pigmentation.

Morphological characterization of isolated fungi viz., shape, size and septation of mycelium and spores were recorded. The characteristics observed were compared with authentic descriptions of Nelson et al., (1983) and Sneh et al., (1998). Pathogenicity was established by following Koch's postulates. For determination of isolation frequencies of root rot pathogens, three segments per root system were selected from ten randomly selected plants of each site. The number of isolates of fungal pathogens isolated from sampled root segments was determined and mean isolation frequency rates were calculated as the number of isolates of selected fungus from 30 sampled root bits. 
Isolation, characterization and identification of biocontrol agents

Ectomycorrhizae were collected underneath the fir plantation from three fir dominated forests. For isolation and culture of fungus, a shallow cut 1-2 mm deep to the sporocarp across the middle of cap along one side of the stipe to expose interior tissue. The tissue bits of 2-5 $\mathrm{mm}$ size from the expose interior surface were cut, loosened and aseptically transferred to the petri-plates containing modified Melin-Norkarn's medium (MMN) Marx, 1969. Plates were incubated for 25 days at $25 \pm 2^{\circ} \mathrm{C}$ and regularly monitored for any mycelial growth. The colonies developed were studied for mycelial growth, colour and pigmentation. Morphological characteristics of isolated fungi viz., shape, size and septation of spores were also recorded. The macrofungi were identification on the basis of shape, size, colour and ornamentation of sporocarp and spores. The characters depicted by each fungus were compared with authentic description given by Godbout and Fotin (1985) and Lakhanpal (1988).

Rhizospheric soil from fir dominant areas was collected and rhizospheric antagonistic fungi were isolated using dilution plate technique and cultured on PDA (Elad et al., 1981). The antagonists were identified on the basis of their morpho-cultural characteristics and spore characters and compared with authentic descriptions (Bissett, 1991; Gams and Bissett, 1998; Samuels, 2006). Both mycorrhizal and rhizospheric isolates were screened for their bio-control potential against fir root rot pathogens.

\section{In vitro screening of bio-control agents against pathogens}

The in vitro antagonism in dual culture between ectomycorrhizal and the root rot pathogens was studied on MMN agar according to Marx (1969). Five mm disc of 20 days old mycelial mat was placed about $2 \mathrm{~cm}$ away from the edge of $90 \mathrm{~mm}$ petri-plate containing $25 \mathrm{ml} \mathrm{MMN}$ agar medium. Fifteen days later $5 \mathrm{~mm}$ mycelial disc of test pathogen was placed on the opposite side of the plate, $4 \mathrm{~cm}$ away from the mycelial margin of the symbiont. Observations with respect to zone of inhibition on growth of the pathogen in dual culture as well as in control plates were recorded ten days after incubation. Antagonistic activity of rhizospheric fungal isolates against the test pathogens was assessed by dual culture technique (Utkhade and Rahe, 1983). Five $\mathrm{mm}$ mycelial discs each of ten days old culture of test pathogens and bio-control agents were placed on the fresh PDA plates about $60 \mathrm{~mm}$ apart in $90 \mathrm{~mm}$ petri-plate and incubated at $25 \pm 2^{\circ} \mathrm{C}$. The petri-plates with pathogen disc only served as control. Three replications for each treatment were was laid out in a completely randomized design. Observations with respect to zone of inhibition on growth of the pathogen in dual culture as well as in control plates were recorded 7 days after incubation. The per cent inhibition in mycelial growth of the pathogen over control was calculated using formula given by Vincent (1947). For mass multiplication, ectomycorrhizal fungi were mass multiplied on peat moss mixture as per the method given by Marx and Bryan (1975) and fungal bioagents were mass multiplied on wheat bran (Younis et al., 2010).

\section{In vitro evaluation of fungitoxicants against the pathogens}

In vitro evaluation of various fungitoxicants to check the colony growth of the isolated pathogens evaluated through poisoned food technique on potato dextrose agar (PDA) medium (Borum and Sinclair, 1968). The experiment was conducted in completely randomized design (CRD) with 9 treatments 
and 3 replications. Five systemic fungitoxicants viz., hexaconazole $5 \mathrm{EC}$, triadimefan $25 \mathrm{WP}$, carbendazim, 50WP, thiophonate methyl $70 \mathrm{WP}$, metalaxyl $68 \mathrm{WP}$, were tested each at $0.010 \%, 0.015 \%, 0.020 \%$, $0.025 \%$ and $0.030 \%$ and four non-systemic fungitoxicants viz., copper oxychloride 50 $\mathrm{WP}$, mancozeb $75 \mathrm{WP}$, chlorothalonil $75 \mathrm{WP}$ and captan $50 \mathrm{WP}$, were tested each at $0.10 \%$, $0.15 \%, \quad 0.20 \%, \quad 0.25 \%$ and $0.30 \%$ on formulation basis. $25 \mathrm{ml}$ of PDA medium amended with fungicides in 5 different concentrations in separate $100 \mathrm{ml}$ flasks was poured in petri-plates. The PDA medium without fungitoxicants was kept as control. 5 $\mathrm{mm}$ fungal disc of each test pathogen was picked from there purified cultures and inoculated in the center of each petri plate. Three replicate plates were inoculated for each fungitoxicant concentration. The inoculated plates were incubated at $25 \pm 2{ }^{\circ} \mathrm{C}$ and mean colony diameter was measured once the control petri-plates get full growth. The percent inhibition in growth due to various fungicidal treatments at different concentrations was computed as follows:

Mycelial growth inhibition $(\%)=[(\mathrm{dc}-\mathrm{dt}) / \mathrm{dc}]$ $\times 100$

Where $\mathrm{dc}=$ average diameter of fungal colony in control, and

$\mathrm{dt}=$ average diameter of fungal colony in treatment group

\section{Preparation of sick soil}

Soil collected from SKUAST-K, main campus, was mixed with sand and forest litter in the ratio of $2: 1: 1(\mathrm{w} / \mathrm{w})$. The mixture was then autoclaved at $1.05 \mathrm{~kg}$ per $\mathrm{cm}^{2}$ for one hour for three consecutive days. One $\mathrm{kg}$ of potting mixture was put into each polythene bag of $1.5 \mathrm{~kg}$ capacity. The mass multiplied pathogenic inoculum @ $10 \mathrm{~g} / \mathrm{kg}$ of mixture was incorporated 25 days before seedling transfer to develop sick soil culture.

\section{Inoculation and seed sowing}

The interaction studies between most frequently occurring pathogen (Fusarium oxysporum f.sp. pini), most effective antagonists, ectomycorrhizae and fungitoxicants two from each were conducted in a polyhouse wherein a temperature of $25 \pm 2^{\circ} \mathrm{C}$ was maintained. The antagonists were inoculated singly and in combination @ 10 $\mathrm{g} / \mathrm{kg}\left(1 \times 10^{-6} \mathrm{cfu}\right)$ of mixture 7 days before seedling transfer and mixed properly. Mass multiplied ectomycorrhizal inocula @ $10 \mathrm{~g} / \mathrm{kg}$ were added simultaneously with seedling transfer. The fungitoxicants (systemic @ $0.1 \%$ and non-systemic @ 0.3\%) were applied as soil drench to the potting mixture 15 days after seedling transfer.

Five pre-germinated seeds having approximately 3-5 $\mathrm{mm}$ long hypocotyls were transplanted to each polybag and after establishment only one seedling was maintained per bag. The observations with respect to disease intensity, shoot length, root length, fresh weight, dry weight and sturdiness quotient were recorded on $300^{\text {th }}$ day after seedling transplantation (DAT). Dry biomass of seedlings was determined by drying the plants at $60^{\circ} \mathrm{C}$ for 48 hours in a hot air oven. The experiment was laid in a randomized block design with three replications for each treatment. Sturdiness quotient was recorded by employing the formula given by Jaenicke (1999) which is as follows:

Sturdiness Seedling height

quotient $=$

$\frac{(\mathrm{cm})}{\text { Collar diameter }} \times 100$

The data wherever desired was subjected to appropriate transformations prior to analysis as suggested by Gomez and Gomez (1984). 


\section{Results and Discussion}

To assess the status of root rot in fir (Abies pindrow) seedlings in Kashmir valley, three major fir growing nurseries Seer and Nangdandi (Anantnag) and Tangmarg (Baramulla) were surveyed during two consecutive years 2013 and 2014. The survey was conducted thrice in a year starting from May at two months interval and the data obtained is presented in tables 1 and 2 . The mean disease incidence at the locations surveyed varied from 24.6 to 36.7 per cent with maximum disease at Tangmarg and minimum at Seer. The disease incidence was higher in the year 2014 (32.2\%) than in 2013 (29.3\%). During the year 2013 mean disease incidence varied from 23.6 to 35.1 per cent while in the year 2014 it varied from 25.8 to 38.3 per cent. The disease shows progressive increase with time. The trend was same in both the years with maximum disease incidence 42.5 and 45.5 per cent noticed in November in 2013 and 2014, respectively, recorded at Tangmarg and least incidence of 27.3 to 30.0 per cent at Seer. Disease incidence at three locations varied significantly.

However, in the month of November highest disease incidence 44.0 per cent was recorded at Tangmarg which was statistically higher than 36.5 and 28.6 per cent recorded in Nangdandi and Seer, respectively. Disease incidence in the month of August at Tangmarg was 36.0 per cent which was statistically high with disease incidence in month of August at Nangdandi (30.2\%) and Seer $(24.2 \%)$ but proved statistically at par with November month disease incidence at Nangdandi. Least disease incidence was noticed in the month of May at Seer was 21.2 per cent which was statistically less with disease incidence in the month of May at Nangdandi $(26.5 \%)$. and Tangmarg 30.2 per cent. Disease incidence at Nangdandi in the month of May was 26.5 per cent which was statistically at par with disease incidence in the month of August (24.2\%) at Seer. This significant increase may be attributed to favorable climatic and disease development conditions that existed during the period. Since the data recorded from two meterological stations representing the areas of surveyed nurseries indicating the higher precipitation and temperature during 2014 than recorded during 2013. During the year 2014 precipitation and temperature at Gulmarg (Baramulla) was 713.0 millimeters and $16.4^{\circ} \mathrm{C}$ and at Kokarnag (Anantnag) 692.8 millimeters, and $22.3^{\circ} \mathrm{C}$ in comparison to 2013 precipitation 493.0 millimeters, temperature $17.8^{\circ} \mathrm{C}$ and 530.3 millimeters and $23.3^{\circ} \mathrm{C}$ at Gulmarg (Baramulla) and Kokarnag (Anantnag), respectively. High precipitation and warm weather had favours the pathogens so the root rot disease shows progressive increase with time. Ahanger et al., (2011) was also of this opinion that warm weather (25$35^{\circ} \mathrm{C}$ ) favours the pathogen to induce losses and predispose the conifers to infection by the root rot pathogens.

Two years pooled data revealed that the mean disease intensity at the locations surveyed varied from 22.9 to 32.7 per cent with maximum disease intensity at Tangmarg and least at Seer. The disease intensity was significantly higher in the year $2014(29.3 \%)$ as compared to (24.7\%) recorded during 2013. Disease intensity at the locations surveyed varied from 20.4 to 30.5 per cent and 25.5 to 35.0 per cent in the year 2013 and 2014, respectively. Comparison of two year data revealed least disease intensity of 22.9 per cent was recorded at Seer which was significantly lower than 25.4 per cent at Nangdandi. Maximum disease intensity was recorded at Tangmarg (32.7\%) which shows significant difference with Nangdandi and Seer. Vaartaja and Morgan (1981) while working on root rot diseases in conifer 
seedlings observed that high moisture content in the substrate favours the development of root rot pathogens. Similarly, Menkis et al., (2005) reported that dry sandy loam substrate contributed to the low incidence of root rot pathogens of conifer seedlings.

Isolations from diseased roots of fir seedlings, collected during survey, revealed the presence of various pathogens viz., Fusarium oxysporum f.sp. pini, $F$. solani, $F$. pallidoroseum, Rhizoctonia solani, Sclerotium rolfsii and Pythiun sp. Fusarium oxysporum f.sp.pini, was the most frequently isolated fungus with maximum frequency of $30.0 \%$, whereas $F$. solani. $F$. pallidoroseum, $R$. solani, $S$. rolfsii and Pythium sp showed isolation frequencies of 22,18,12, 10 and $8 \%$ respectively (Table 3 ). Initial symptoms in $F$. oxysporum f.sp. pini, $F$. solani and $F$. pallidoroseum inoculated seedlings developed after $45^{\text {th }}, 47^{\text {th }}$ and $52^{\text {th }}$, day whereas in Rhizoctonia solani, Sclerotium rolfsii and Pythiun sp. after $55^{\text {th }}$ and $50^{\text {th }}$ day of seedling transplantation to sick soil, respectively (Table 4).

Seedlings showed wilting of shoots, retarded growth, yellowing of needles and shredding of roots. Roots had developed partial or total rot, ultimately leading to death of root system and finally the whole plant. Menkis et al., (2005) recorded 44.6 per cent isolation frequency of $F$. oxysporum from colonized roots of Pinus sylvestris seedlings and 0.3 per cent isolation frequency of $R$. solani from the diseased roots of Picea abies seedlings from Uppsala Sweden.

Ahanger et al., (2011) were of this opinion that $F$. oxysporum as the most abundant pathogenic fungus in diseased roots of blue pine seedlings with isolation frequency of $38.6 \%$ where as Rhizoctonia solani and Macrophomina phaseolina showed isolation frequencies of 11.0 and 3.3 per cent, respectively.
Eight dominant ectomycorrhizal sporocarps (Boletus edulis, Boletus rhodoxanthus, Laccaria laccata, Laccaria bicolor, Suillus granulatus, Suillus placidus, Russula lutea and Russula emetica) were collected, identified, their ectomycorrhizal nature was established by observing their mycelial mat connections with feeder root tips. Isolations of ectomycorrhizal fungi were made on modified Melin-Norkans (MMN) agar medium from the sporocarps. Ten Trichoderma isolates were identified and isolated on PDA medium from fir rhizosphere. All the bio-control agents (ectomycorrhizal and rhizospheric antagonists) were screened against the isolated root rot fungi. Laccaria laccata, Boletus edulis, Russula lutea and Suillus placidus also have previously been reported and identified by Beig et al., (2011) from Kashmir forests.

In vitro interactions between rhizospheric antagonists, ectomycorrhizal fungi and root rot pathogens (Fusarium oxysporum f.sp. pini, $F$. solani, $F$. pallidoroseum, Rhizoctonia solani, Sclerotium rolfsii and Pythium sp.) revealed that all the tested bio-agents including mycorrhizae inhibited the mycelial growth of pathogens with varied degrees of inhibition (Table 4). The mycelial growth inhibitions ranged from 12.0 to 76.4 per cent. The maximum inhibition $(60.2 \%)$ was exhibited by Trichoderma harzianum TG1 followed by $T$. viride TG2 with 58.3-75.8 per cent inhibition. Trichoderma harzianum TG1 and $T$. viride $\mathrm{TG} 2$ caused twisting around the pathogenic hyphae and ultimately leading to lysis of parasitized hyphae. Mycorrhizae depicted strong mycoparasitic activity and showed significant antagonistic activity against root rot pathogens. Boletus edulis and Laccaria laccata developed zone of inhibition against the pathogens and caused 55.0-65.2 to 52.4-62.5 per cent mycelial growth inhibition. The involvement of strong antabiosis due to production of volatile metabolites and 
diffusible chemicals is suggested for the formation zone of inhibition. Duchesne et al., (1987) were of this opinion that antagonistic action of $L$. laccata may be attributed to the release of substantial antibiotics and other antimicrobial metabolites against the root rot pathogens. The mycoparasitic activity of ectomycrrhizal fungi against root rot pathogen $R$. solani has earlier been suggested by Zhao and Kuo (1988). Our findings are in agreement with Amin et al., (2010) and Jeyaseelan et al., (2012) who reported that the application of Trichoderma sp. effectively controls a large number of soil borne fungi including S. rolfsii, $R$. solani, Pythium sp. $F$. solani, $F$. oxysporum and $F$. pallidoroseum in vegetables.

Table.1 Cumulative root rot incidence on fir seedlings in major fir growing nurseries of Kashmir valley during the year 2013 and 2014

\begin{tabular}{|c|c|c|c|c|c|}
\hline \multirow{2}{*}{ District } & \multirow{2}{*}{ Location } & \multirow{2}{*}{ Month } & \multicolumn{3}{|c|}{ Root rot incidence (\%) } \\
\hline & & & 2013 & 2014 & Mean \\
\hline \multirow[t]{8}{*}{ Anantnag } & Nagdandi & May & $25.5(30.3)$ & $27.5(31.6)$ & $26.5(30.9)^{d}$ \\
\hline & & August & $28.4(32.2)$ & $32.0(34.4)$ & $30.2(33.3)^{c}$ \\
\hline & & November & $34.5(35.9)$ & $38.5(38.3)$ & $36.5(37.1)^{b}$ \\
\hline & & Mean & $29.4(32.8)^{\mathrm{BI}}$ & $32.6(34.7)^{\mathrm{B}}$ & $31.0(33.7)$ \\
\hline & Seer & May & $20.0(26.5)$ & $22.4(28.2)$ & $21.2(27.3)^{\mathrm{e}}$ \\
\hline & & August & $23.5(28.9)$ & $25.0(30.0)$ & $24.2(29.4)^{d}$ \\
\hline & & November & $27.3(31.4)$ & $30.0(33.2)$ & $28.6(32.3)^{\mathrm{c}}$ \\
\hline & & Mean & $23.6(28.9)^{\mathrm{Cl}}$ & $25.8(30.4)^{C}$ & $24.6(29.6)$ \\
\hline \multirow[t]{4}{*}{ Baramulla } & Tangmarg & May & $28.4(32.2)$ & $32.2(34.5)$ & $30.2(33.3)^{\mathrm{c}}$ \\
\hline & & August & $34.5(35.9)$ & $37.5(37.7)$ & $36.0(36.8)^{b}$ \\
\hline & & November & $42.5(40.6)$ & $45.5(42.4)$ & $44.0(41.5)^{\mathrm{a}}$ \\
\hline & & Mean & $35.1(36.2)^{\mathrm{AI}}$ & $38.3(38.2)^{A}$ & $36.7(37.2)$ \\
\hline \multicolumn{3}{|c|}{ Overall mean } & $29.3(32.6)$ & $32.2(34.4)$ & - \\
\hline \multicolumn{3}{|c|}{$C D(p=0.05)$} & 2.5 & 1.9 & 2.2 \\
\hline
\end{tabular}

Figures in parenthesis are arc sine transformed value; Values superscripted with same letter (s) are statistically identical

Table.2 Root rot intensity on fir seedlings in major fir growing nurseries of Kashmir valley during the year 2013 and 2014

\begin{tabular}{|l|l|l|l|l|}
\hline \multirow{2}{*}{ District } & \multirow{2}{*}{ Location } & \multicolumn{4}{|l|}{ Root rot intensity (\%) } \\
\cline { 3 - 5 } & & 2013 & 2014 & Mean \\
\hline Anantnag & Nagdandi & $23.3(28.8)$ & $27.5(31.6)$ & $25.4(30.2) \mathrm{b}$ \\
\hline Anantnag & Seer & $20.4(26.8)$ & $25.5(30.3)$ & $22.9(28.8) \mathrm{b}$ \\
\hline Baramulla & Tangmarg & $30.5(33.5)$ & $35.0(36.2)$ & $32.7(34.6) \mathrm{a}$ \\
\hline Mean & & $24.7(29.7)$ & $29.3(32.7)$ & $27.0(31.2)$ \\
\hline CD $(\mathrm{p}=0.05)$ & 1.7 & 1.2 & 1.4 \\
\hline
\end{tabular}

Figures in parenthesis are arc sine transformed value; Values superscripted with same letter (s) are statistically identical 
Table.3 Isolation frequency (\%) of root rot fungi and time taken for symptom expression in fir seedlings

\begin{tabular}{|l|c|c|}
\hline Pathogen & $\begin{array}{c}\text { Frequency of isolation } \\
\text { (\%age) }\end{array}$ & $\begin{array}{c}\text { Days taken for symptom } \\
\text { expression }\end{array}$ \\
\hline Fusarium oxysporum f.sp.pini & 30 & 45 \\
\hline Fusarium solani & 22 & 47 \\
\hline Fusarium pallidoroseum & 18 & 52 \\
\hline Rhizoctonia solani & 12 & 55 \\
\hline Sclerotium rolfsii & 10 & 55 \\
\hline Pythium sp & 8 & 50 \\
\hline
\end{tabular}

Table.4 Mycelial growth inhibition (\%) and zone of inhibition of fir root rot pathogens caused by potential bio-agents

\begin{tabular}{|c|c|c|c|c|c|c|}
\hline \multirow{2}{*}{$\begin{array}{l}\text { Fungal/mycorrhizal } \\
\text { species }\end{array}$} & \multicolumn{6}{|c|}{ Root rot pathogens } \\
\hline & $\begin{array}{l}\text { Fusarium } \\
\text { oxysporum }\end{array}$ & $\begin{array}{l}\text { Fusarium } \\
\text { pallidoroseum }\end{array}$ & $\begin{array}{l}\text { Fusariu } \\
\text { m solani }\end{array}$ & $\begin{array}{l}\text { Sclerotium } \\
\text { rolfsii }\end{array}$ & $\begin{array}{l}\text { Rhizoctonia } \\
\text { solani }\end{array}$ & $\begin{array}{l}\text { Pythium } \\
\text { sp. }\end{array}$ \\
\hline $\begin{array}{l}\text { Trichoderma } \\
\quad \text { harzianum } \mathrm{TG}_{1}\end{array}$ & $76.4(+)$ & $73.0(+)$ & $70.5(+)$ & $72.0(+)$ & $74.8(+)$ & $60.2(+)$ \\
\hline T. viride TG2 & $75.8(+)$ & $72.0(+)$ & $68.3(+)$ & $68.6(+)$ & $73.9(+)$ & $58.3(+)$ \\
\hline T. viride TG3 & $74.6(+)$ & $71.5(+)$ & $65.2(+)$ & $68.0(+)$ & $70.3(+)$ & $55.5(-)$ \\
\hline T. harzinum $\mathrm{TG}_{4}$ & $70.0(+)$ & $67.5(+)$ & $63.3(+)$ & $64.6(+)$ & $70.1(+)$ & $52.3(+)$ \\
\hline T. harzianum $\mathrm{TG}_{5}$ & $74.0(+)$ & $65.3(+)$ & $60.1(+)$ & $67.3(+)$ & $45.3(-)$ & $53.2(+)$ \\
\hline T. viride TG6 & $73.5(+)$ & $54.8(+)$ & $45.8(-)$ & $61.2(+)$ & $69.7(+)$ & $45.8(-)$ \\
\hline T. viride TG7 & $40.2(-)$ & $36.2(-)$ & $33.3(-)$ & $18.0(-)$ & $16.1(-)$ & $24.4(-)$ \\
\hline T. harzianum $\mathrm{TG}_{8}$ & $34.2(-)$ & $24.6(-)$ & $18.0(-)$ & $34.6(-)$ & $39.5(-)$ & $32.5(-)$ \\
\hline T. harzianum TG9 & $38.2(-)$ & $25.2(-)$ & $39.5(-)$ & $36.4(-)$ & $42.1(-)$ & $14.0(-)$ \\
\hline T. viride $\mathrm{TG}_{10}$ & $25.3(-)$ & $17.3(-)$ & $37.6(-)$ & $25.5(-)$ & $34.5(-)$ & $26.0(-)$ \\
\hline Boletus edulis & $65.2(+)$ & $62.8(+)$ & $65.0(+)$ & $62.2(+)$ & $63.0(+)$ & $55.0(-)$ \\
\hline B. rhodoxanthus & $49.0(-)$ & $65.0(-)$ & $64.5(-)$ & $56.2(-)$ & $40.0(-)$ & $42.2(-)$ \\
\hline Laccaria laccata & $62.5(+)$ & $60.6(+)$ & $63.0(+)$ & $60.8(+)$ & $60.0(+)$ & $52.4(-)$ \\
\hline Laccaria bicolor & $51.5(-)$ & $31.0(-)$ & $33.3(-)$ & $12.0(-)$ & $34.2(-)$ & $34.2(-)$ \\
\hline Suillus granulatus & $36.2(-)$ & $33.3(-)$ & $21.3(-)$ & $15.3(-)$ & $12.1(-)$ & $21.3(-)$ \\
\hline Suillus placidus & $31.2(-)$ & $21.3(-)$ & $15.2(-)$ & $36.2(-)$ & $37.2(-)$ & $31.5(-)$ \\
\hline Russula lutea & $36.5(-)$ & $23.2(-)$ & $37.2(-)$ & $34.6(-)$ & $40.1(-)$ & $12.1(-)$ \\
\hline Russula emetica & $21.3(-)$ & $15.3(-)$ & $34.6(-)$ & $23.8(-)$ & $31.5(-)$ & $25.1(-)$ \\
\hline
\end{tabular}

$*$ The (+) indicates the presence of zone of inhibition while (-) indicates the absence of zone 
Table.5 In vitro efficacy of systemic fungitoxicants in inhabiting the mycelial growth of test pathogens

\begin{tabular}{|l|l|l|l|l|l|l|}
\hline \multirow{2}{*}{$\begin{array}{l}\text { Fungitoxicants/ } \\
\text { Concentrations }\end{array}$} & \multicolumn{5}{|l}{ Mean mycelial growth inhibition (\%) at different concentrations } \\
\cline { 2 - 7 } & $0.010 \%$ & $0.015 \%$ & $0.020 \%$ & $0.025 \%$ & $0.030 \%$ & Mean \\
\hline $\begin{array}{l}\text { Thiophenate } \\
\text { Methyl 70 WP }\end{array}$ & $50.5(45.2)$ & $64.2(52.4)$ & $83.3(65.8)$ & $100.0(90.0)$ & $100.0(90.0)$ & $79.6(68.6)^{\mathrm{b}}$ \\
\hline $\begin{array}{l}\text { Hexaconazole } \\
\text { 5EC }\end{array}$ & $42.5(40.6)$ & $54.5(47.5)$ & $72.4(58.3)$ & $85.5(67.6)$ & $100.0(90.0)$ & $70.9(60.8)^{\mathrm{c}}$ \\
\hline $\begin{array}{l}\text { Triadimefon } 25 \\
\text { WP }\end{array}$ & $40.2(39.3)$ & $52.5(46.4)$ & $65.0(53.7)$ & $76.5(61.0)$ & $92.4(73.9)$ & $65.3(54.8)^{\mathrm{d}}$ \\
\hline $\begin{array}{l}\text { Carbendazim } \\
\text { WP }\end{array}$ & $55.6(48.2)$ & $68.3(55.7)$ & $86.0(68.0)$ & $100.0(90.0)$ & $100.0(90.0)$ & $81.9(70.3)^{\mathrm{a}}$ \\
\hline Mean & $47.2(43.3)^{\mathrm{E}}$ & $59.8(50.5)^{\mathrm{D}}$ & $76.6(61.4)^{\mathrm{C}}$ & $90.5(77.1)^{\mathrm{B}}$ & $98.1(85.9)^{\mathrm{A}}$ & - \\
\hline
\end{tabular}

Figures in parenthesis are arc sine transformed value; Values superscripted with same letter (s) are statistically identical

$\mathrm{CD}(\mathrm{p}=0.05)$

Fungicide (A) $\quad 1.2$

Concentration (B) $\quad 1.2$

$(\mathrm{A} \times \mathrm{B}) \quad 2.0$

Table.6 In vitro efficacy of non-systemic fungitoxicants in inhabiting the mycelial growth test pathogens

\begin{tabular}{|c|c|c|c|c|c|c|}
\hline \multirow{2}{*}{$\begin{array}{l}\text { Fungitoxicants/ } \\
\text { Concentrations }\end{array}$} & \multicolumn{6}{|c|}{ Mean mycelial growth inhibition (\%) at different concentrations } \\
\hline & $0.10 \%$ & $0.15 \%$ & $0.20 \%$ & $0.25 \%$ & $0.30 \%$ & Mean \\
\hline Captan 50 WP & $30.2(34.4)$ & $42.5(39.3)$ & $53.3(45.2)$ & $65.7(52.8)$ & $80.0(62.0)$ & $54.3(46.7)^{d}$ \\
\hline Mancozeb $75 \mathrm{WP}$ & $55.3(46.8)$ & $62.5(51.0)$ & $74.4(57.0)$ & $86.5(65.0)$ & $100.0(90.0)$ & $75.7(61.9)^{\mathrm{a}}$ \\
\hline $\begin{array}{l}\text { Coperoxychloride } \\
50 \mathrm{WP}\end{array}$ & $36.8(37.3)$ & $45.7(42.5)$ & $58.2(49.7)$ & $74.5(59.6)$ & $92.5(74.1)$ & $61.5(52.6)^{\mathrm{c}}$ \\
\hline $\begin{array}{l}\text { Chlorothalonil } 75 \\
\text { WP }\end{array}$ & $40.2(40.6)$ & $52.5(46.4)$ & $63.3(52.7)$ & $75.5(60.3)$ & $90.0(71.5)$ & $64.3(54.3)^{b}$ \\
\hline Mean & $40.6(39.7)^{\mathrm{E}}$ & $50.8(44.8)^{\mathrm{D}}$ & $62.3(51.1)^{C}$ & $75.5(59.4)^{\mathrm{B}}$ & $90.6(74.4)^{A}$ & - \\
\hline
\end{tabular}

Figures in parenthesis are arc sine transformed value; Values superscripted with same letter (s) are statistically identical $\mathrm{CD}(\mathrm{p}=0.05)$

Fungicide (A)

Concentration (B)

1.0

$(\mathrm{A} \times \mathrm{B})$

1.0

2.4 
Table.7 Influence of fungitoxicants, antagonists and ectomycorrhizae individually and in combination on disease intensity, growth parameters and sturdinesss quotient of fir seedlings grown in F. oxysporum f.sp. pini sick soil on $300^{\text {th }}$ days after seedling transplantation

\begin{tabular}{|c|c|c|c|c|c|c|c|}
\hline Treatments & $\begin{array}{l}\text { Disease } \\
\text { intensity }\end{array}$ & $\begin{array}{l}\text { Shoot } \\
\text { length } \\
(\mathrm{cm})\end{array}$ & $\begin{array}{l}\text { Root } \\
\text { length } \\
(\mathrm{cm})\end{array}$ & $\begin{array}{l}\text { Collar } \\
\text { diamete } \\
\mathrm{r}(\mathrm{mm})\end{array}$ & $\begin{array}{l}\text { Sturdines } \\
\text { s quotient } \\
\text { (cm) }\end{array}$ & $\begin{array}{l}\text { Fresh } \\
\text { weigh } \\
\mathrm{t}(\mathrm{mg}) \\
\end{array}$ & $\begin{array}{l}\text { Dry } \\
\text { weight } \\
(\mathrm{mg})\end{array}$ \\
\hline F. oxysporum (control) & 93.3 & 3.1 & 3.7 & 7 & 0.97 & 170 & 70 \\
\hline Carbendazim & 35.5 & 8.7 & 9.3 & 13 & 1.38 & 500 & 210 \\
\hline Mancozeb & 46.5 & 5.5 & 6.7 & 10 & 1.22 & 375 & 160 \\
\hline Trichoderma harzianum & 56.0 & 4.0 & 5.1 & 8 & 1.13 & 270 & 125 \\
\hline Trichoderma viride & 56.5 & 3.8 & 4.8 & 8 & 1.08 & 267 & 123 \\
\hline Boletus edulis & 59.0 & 3.5 & 4.4 & 8 & 1.00 & 264 & 116 \\
\hline Laccaria laccata & 58.4 & 3.7 & 4.6 & 8 & 1.04 & 266 & 118 \\
\hline T. harzianum+ carbendazim & 27.2 & 9.6 & 11.0 & 14 & 1.47 & 616 & 268 \\
\hline T. viride + carbendazim & 27.8 & 9.4 & 10.8 & 14 & 1.44 & 612 & 266 \\
\hline B. edulis + carbendazim & 29.8 & 9.0 & 10.3 & 14 & 1.39 & 608 & 263 \\
\hline L. laccata + carbendazim & 29.2 & 9.2 & 10.6 & 14 & 1.41 & 610 & 265 \\
\hline T. harzianum + mancozeb & 40.4 & 8.0 & 8.4 & 12 & 1.33 & 478 & 208 \\
\hline T. viride + mancozeb & 41.5 & 7.8 & 8.1 & 12 & 1.30 & 476 & 205 \\
\hline B. edulis + mancozeb & 42.8 & 7.2 & 7.6 & 12 & 1.22 & 472 & 200 \\
\hline L. laccata + mancozeb & 42.2 & 7.4 & 7.8 & 12 & 1.25 & 474 & 203 \\
\hline T. harzianum + B. edulis & 51.5 & 4.8 & 5.5 & 9 & 1.14 & 295 & 142 \\
\hline T. harzianum + L. laccata & 50.2 & 4.9 & 5.8 & 9 & 1.19 & 297 & 145 \\
\hline T. viride + B. edulis & 52.8 & 4.4 & 5.2 & 9 & 1.07 & 292 & 135 \\
\hline T. viride + L. laccata & 52.0 & 4.5 & 5.3 & 9 & 1.09 & 293 & 138 \\
\hline $\begin{array}{l}\text { T. harzianum+B..edulis }+ \\
\text { carbendazim }\end{array}$ & 13.6 & 12.6 & 14.2 & 16 & 1.68 & 824 & 365 \\
\hline $\begin{array}{l}\text { T. harzianum+L.laccata+ } \\
\text { carbendazim }\end{array}$ & 13.2 & 13.0 & 14.6 & 16 & 1.72 & 825 & 368 \\
\hline $\begin{array}{l}\text { T. harzianum + B. edulis + } \\
\text { mancozeb }\end{array}$ & 18.0 & 10.5 & 12.7 & 15 & 1.56 & 698 & 305 \\
\hline $\begin{array}{l}\text { T. harzianum + L. laccata }+ \\
\text { mancozeb }\end{array}$ & 17.3 & 10.7 & 13.1 & 15 & 1.59 & 700 & 307 \\
\hline $\begin{array}{l}\text { T. viride }+ \text { B. edulis }+ \\
\text { carbendazim }\end{array}$ & 16.0 & 12.0 & 13.8 & 16 & 1.61 & 820 & 360 \\
\hline $\begin{array}{l}\text { T. viride + L. laccata + } \\
\text { carbendazim }\end{array}$ & 14.8 & 12.5 & 14.0 & 16 & 1.65 & 822 & 363 \\
\hline T. viride + B. edulis + mancozeb & 19.0 & 10.2 & 12.0 & 15 & 1.50 & 695 & 300 \\
\hline T. viride + L. laccata + mancozeb & 18.4 & 10.3 & 12.5 & 15 & 1.54 & 696 & 303 \\
\hline $\mathrm{CD}(\mathrm{p}=0.05)$ & 2.1 & 1.1 & 1.0 & 3.2 & 0.04 & 4.0 & 3.0 \\
\hline
\end{tabular}

The studies on in vitro evaluation of fungitoxicants against the root rot pathogens (Fusarium oxysporum f.sp. pini, F. solani, F. pallidoroseum, Rhizoctonia solani, Sclerotium rolfsii and Pythium sp.) through poison food technique. Mycelial growth inhibition of each pathogen at each concentration was recorded and the mean mycelial growth inhibition of all 
the pathogens is presented in tables 5 and 6 . The data presented in the tables 5 and 6 revealed that the systemic fungitoxicant carbendazim exhibited highest mycelial growth inhibition $100.0 \%$ at $0.03 \%$ and nonsystemic fungitoxican mancozeb exhibited highest mycelial growth inhibition $100.0 \%$ at $0.30 \%$. Mycelial growth inhibition increases with increase in fungitoxicant concentration. Complete inhibition of colony growth of $F$. solani was observed by using benlate and carbendazim @ 100 ppm in bottle gourd (Nasreen and Ghaffar, 2010). The results obtained are in agreement to Kumar et al., (2011) reported that Carbendazim and Vitavax were found to be more effective, showing $100 \%$ inhibition of mycelial growth of Rhizoctonia bataticola at $50 \mathrm{ppm}$ followed by Kitazin which showed $100 \%$ inhibition at $100 \mathrm{ppm}$. Thiram, Blitox and Captan were the least effective.

In vivo experiments were laid to evaluate the most effective bio-agents (T. harzianum TG1, T. viride TG2, L. laccata and B. edulis) and fungitoxicants (carbendazim and mancozeb) individually or in combination for the management of most frequently isolated root rot pathogen (Fusarium oxysporum f.sp. pini) manipulated sick soil. All the bio-agents (antagonists and mycorrhizae) and fungitoxicants singly or in combination, significantly reduced root rot intensity as well as increased root length, shoot length, fresh weight and dry weight in fir seedlings in comparison to control (Fusarium inoculation alone) (Table 7). The percentage of disease reduction varied among treatments however, treatment combinations of bio-agents and fungitoxicant showed better results than their individual performances. In their, individual capacity, fungitoxicants proved significantly superior over bio-agents in reducing the disease intensity and increasing biomass. Among all individual treatments minimum root rot intensity $(35.3 \%)$ and maximum shoot length $(8.7 \mathrm{~cm})$, root length $(9.3 \mathrm{~cm})$, fresh weight $(500 \mathrm{mg})$ and dry weight $(210$ $\mathrm{mg}$ ) were recorded in carbendazim in comparison to control. Statistical analysis indicated that all the bio-agents with disease intensity ranging between 56.0-59.0 per cent were at par with each other. Among the treatments components used singly maximum disease reduction over control of 61.9 per cent was recorded in carbendazim and least of 36.7 per cent in $B$. edulis. Antagonists in rhizosphere compete with pathogen for host surface and nutrients as well as inhibit pathogenic growth through antibiosis and mycoparasitism (Howell, 2003). Morsay et al., (2009) reported T. viride resulted in 64.4 per cent suppression of Fusarium infection in tomato plants and increased 73 per cent survival rates. (Sharma, 2011) while working on root rot of Pisum sativum recorded 83 per cent disease control by carbendazim in comparison to 50 per cent by T. harzianum.

Dual combination of treatment components proved statistically superior to their individual performances in reducing the disease intensity ranged between 27.2 to 52.8 per cent and increases shoot length $(4.4-9.6 \mathrm{~cm})$, root length $(5.2-11.0 \mathrm{~cm})$, fresh weight $(292-616$ $\mathrm{mg})$ and dry weight (135-268 mg). Combinations of bio-agents with fungitoxicants proved statistically superior to the combinations of bio-agents itself. Carbendazim + bio-agents proved significantly effective in reducing disease intensity than mancozeb + bio-agents. Superiority of combined effects of bio-agents and fungitoxicants also has been reported by Suriachandraselvan and Seethuraman (2002) who opined that in comparison to monoinoculations, carbendazim in combination with $T$. viride resulted in highest reduction in root rot mortality of blackgram. Similarly Shashi et al., (2007) reported that inoculation of $T$. harzianum and $P$. fluorescens with carbendazim, copper oxychloride, mancozeb 
and thiophenate - methyl significantly lowered the Fusarium root rot incidence in tomato seedlings.

Among the treatments evaluated, combinations of all the three components (antagonists, mycorrhizal fungi and fungitoxicants) proved highly effective in reducing the disease intensity. On $300^{\text {th }}$ DAT disease intensity varied from 13.2 to 59.0 per cent exhibiting 36.7 to 85.8 per cent disease control with maximum in treatment combination of $T$. harzianum $+L$. laccata + carbendazim and minimum in individual treatment of $B$. edulis. The disease intensity in such combination-treatment was significantly less to the disease intensities observed in their individual or in dual treatment combinations. Least disease intensity of 13.2 per cent was recorded in treatment combination of $T$. harzianum + L. laccata + carbendazim which was statistically at par with 13.6 and 14.8 per cent observed in $T$. harzianum $+B$. edulis + carbendazim and $T$. viride $+L$. laccata + carbendazim, respectively. Disease intensity of 19.0 per cent in treatment combination of T. viride $+B$. edulis + mancozeb was at par with 17.3, 18.0 and 18.4 per cent recorded in T. harzianum + B. edulis + mancozeb, $T$. harzianum + L. laccata + mancozeb and $T$. viride + L. laccata + mancozeb treatments, respectively. The study revealed that the treatment combinations with carbendazim as one component showed lesser disease intensity (13.2 to 16.0 per cent) and proved statistically superior over treatmentcombinations involving mancozeb as fungitoxicants wherein the disease intensity ranged between 17.3 to 19.0 per cent.

The combined inoculation of biocontrol agents, ectomycorrhizal fungi and fungicides in $F$. oxysporum infested soil showed significantly better sturdiness quotient in comparison control. The maximum improvement $(5.5 \%)$ in sturdiness quotient was noticed in treatment where $T$. harzianum + L. laccata + carbendazim and minimum in T. viride $+B$. edulis + mancozeb (4.4\%). Trichoderma harzianum + L. laccata + carbendazim were statistically superior to all the treatments except $T$. harzianum $+B$. edulis + carbendazim, Trichoderma viride + L. laccata + carbendazim, $T$. viride $+B$. edulis + carbendazim which were at par. Trichoderma harzianum + L. laccata + mancozeb were at par with $T$. harzianum $+B$. edulis + mancozeb, $T$. viride $+L$. laccata + mancozeb and $T$. viride $+B$. edulis + mancozeb. Bhan and Sharma (2011) reported that chemicals and seed stratification had increased the sturdiness quotient of apricot seedlings. Natalya et al., (2011) were of this opinion that there was a drastic reduction in height and collar diameter of Pongamia pinnata seedlings due to various diseases. While working root rot of Havea brasiliensis, Ikerodah, et al., (2012) observed that combined effect of $T$. harzianum, triadimefon or tridemorph resulted in linear infestation and increased growth.

\section{References}

Ahanger, M.A., Dar, G.H., Bhat, Z.A. and Sofi, N. 2011. Fungi associated with Pinus wallichiana seedlings in Kashmir. Plant Pathol. J., 10: 42-45.

Amin, F., Razadan, V.K, Mohiddin, F.A, Bhat, K.A. and Sheikh, P.A. 2010. Effect of volatile metabolites of Trichoderma species against seven fungal plant pathogens in vitro. $J$. Phytol., 2: 34-37.

Anonymous, A. 2009. Digest of forest statistics. Jammu and Kashmir Government, Forest Department, Srinagar, India 29-31.

Beig, M.A., Dar, G.H., Khan, N.A. and Ganai, N.A. 2011. Seasonal production of epigeal fungal sporocarps in mixed and pure fir (Abies pindrow) stands in 
Kashmir forests. J. Agri. Technol., 7(5): 1375-1377.

Bhan, S., Sharma, N.C. 2011. Effect of seed stratification and chemical treatments on seed germination and subsequent seedling growth of wild apricot (Prunus armeniaca). Res. J. Agri. Sci., 2: 13-16.

Bissett, J. 1991. A revision of the genus Trichoderma. II. Infrageneric classification. Canadian J. Bot., 69: 2357-2372.

Borum, D.F. and Sinclair, J.B. 1968. Evidence for systemic fungicides protection against Rhizoctonia solani with vitavex in cotton seedlings. Phytopathol., 58: 976- 980.

Dasgupta, M.K. 1988. Principles of Plant Pathology. Allied Publishers Pvt. Ltd., Banglore $1140 \mathrm{p}$.

Douce, G.K., Moorhead, D.J. and Bargoon, C.T. 2002. Forest Pest Control, Special Bulletin 16, College of Agricultural and Environmental Sciences, The University of Georgia, USA, p. 235.

Duchesne, L.C., Peterson, R.L. and Ellis, B.E. 1987. The accumulation of plant produced antimicroibal compounds in response to ectomycorrhizal fungi. Phytoprotection, 68: 17-27.

Elad, Y., Chet, I. and Henis, Y. 1982. Degradation of plant pathogenic fungi by Trichoderma harzianum. Canadian J. Microbiol., 28: 719-725.

Gams, and Bisset, J. 1998. Morphology and identification of Trichoderma, In: (Eds.c Kubicek and G. Harman), Trichoderma and Glocladium. Taylor and frawis, London, UK, PP. 904-915.

Garret, S.D. 1970. Pathogenic Root Infecting Fungi. Cambridge University Press, London, UK, p. 294.

Godbout, C. and Fortin, J.A. 1985. Synthesized ectomycorrhizae of aspen: fungal genus level of structural characterization. Canadian J. Bot., 63: 252-62.
Gomez, A.K. and Gomez, A.A. 1984. Statistical Procedures for Agricultural Research. (2 ${ }^{\text {nd }}$ Ed.) Wiley, New York, USA $680 \mathrm{p}$.

Howell, C.R. 2003. Mechanism employed by Trichoderma species in the biological control of plant diseases: The history and evolution of current concepts. Plant Dis., 87: 4-10.

Ikeroda, O., Omorusi, E.E. and Mokwwunye, M.U.B. 2012. Challenges and progress in the control of white root rot diseases of Heavea brasiliensis in Africa. World Rusel Observation, 4: 12.

Jaenicke, H. 1999. Good Tree Nursery Practises: p 117-180. In Practical Guidelines for Research Nurseries, ICRAF. Nairobi, Kenya.

Jeyaseelan, E.C., Tharmila, S. and Niranjan, K. 2012. Antagonistic activity of Trichoderma spp. and Bacillus spp. against Pythium aphanidermatum isolated from tomato damping-off. Arch. Appl. Sci. Res., 4: 1623-1627.

Juzwik, J. and Rugg, D.J. 1996. Seedling mortality to development of root rot in white pine seedlings in two bare root nurseries. Canadian J. Plant Pathol., 18: 335-41.

Kiswan, J., Pandey, R. and Dadhwal, V.K. 2009. Technical Paper India's Forest and Tree Cover: Contribution as a carbon sink. Indian council of Forestry Research and Education. New Forests, Dehradun, India, 102-05.

Kumar, S., Sharma, S., Pathak, D.V. and Beniwal, J. 2011. Integrated management of Jatropha root rot caused by Rhizoctonia bataticola. J. Trop. Forest Sci., 23: 35-41.

Lakhanpal, T.N. 1988. Morphology and anatomy of ectomycorrhizal fungi from India. p 53-83 In: Proceedings of $6^{\text {th }}$ Mycorrhiza Round Table, New Delhi, India.

Lal, A.K. and Singh, P.P. 2003. Economic 
worth of carbon stored in above ground biomass of Indian forests. Indian Forester, 103: 874-80.

Linderman, R.G., Davis, A.V., Charles, J.M. 2006. Efficacy of chemical and biological agents to suppress Fusarium and Pythium damping-off of container grown Douglas-fir seedlings. Plant Health Progress 1-17.

Luna, R.K. 1996. Conifers, Plantation Trees. [Eds. L. Taruna and A. Aziz]. International Book Distributers, Dehradun. pp. 866-876.

Marx, D.H. 1969. Antagonism of mycorrhizal fungi to root pathogenic fungi and soil bacteria. Phytopathol., 59: 153-163.

Marx, D.H. and Bryan, W.C. 1975. Growth and ectomycorrhizal development of loblolly pine seedlings in fumigated soil infested with the fungal symbiont Pisolithus tinctorius. Forest Sci., 21: 245-254.

Menkis, A., Veslliauskas, R., Taylor, A.F. and Finiay, R. 2005. Fungi in decayed roots of conifer seedlings in forest nurseries, afforested clear-cuts and abandoned farmland. Plant Pathol., 55: 117-129.

Morsy, M.E., Kawi, K.A. and Khalil, M.N.A. 2009. Efficiency of Trichoderma viride and Bacillus subtilis as biocontrol agents against Fusarium solani on tomato plants. Egypt. J. Phytopathol., 37: 47-57.

Nasreeen, S. and Gaffar, A. 2010. Effect of fungicides and microbial antagonists and oil cakes in the control of Fusarium solani, the causal of seed and seedling rot of bottle gourd, bitter gourd and cucumber. Pak. J. Bot., 42: 2931-2934.

Natalya, K., Suryanarayana, V. and Naik, S.T. 2011. Assessment of foliar diseases and its influence on seedling growth parameters of Pongamia pinnata and economic loss assessment. Karnataka J. Agri. Sci., 24: 260-261.

Nelson, P.E., Toussoun, T.A. and Marasas,
W.F.O. 1983. Fusarium species: an illustrated manual for identification. $\mathrm{p}$ 193 In The Pennsylvania State University Press, University Park, USA. Sameuls, G.J. 2006. Trichoderma, systematics the sexual state and ecology. Phytopath., 96: 195- 206.

Sanjay, A. and Kaushik, J.C. 2001. Efficacy of Trichoderma spp. and Gliocladium virens as biocontrol agents against damping-off of forest nurseries. Plant Dis. Res., 16: 46-51.

Sharma, P. 2011. Evaluation of disease control and plant growth promotion potential of biocontrol agents on Pisum sativum and comparison of their activity with popular chemical control agent carbendazim. J. Toxicol. Environ. Health Sci., 3: 127-138.

Shashi, K., Rajkumar, R. and Singh, R.V. 2007. Field efficacy of bioagents and fungicides against tomato (Lycopersicum esculentum Mill.) diseases. Environ. Ecol., 25: 921-924.

Sneh, B., Burpee, L. and Ogoshi, A. 1998. Identification of Rhizoctonia species. American Phytopathological Society Press, St. Paul, Minnesota, USA p 135.

Suriachandraselvan, M. and Seethuraman, K. 2002. Efficacy of Trichoderma viride in combination with fungicides against $M$. phaseolina (Tassi) Goid. infection in blackgram. Madras Agri. J., 89: 512514.

Taylor, A.F. and Alexander, I. 2005. The ectomycorrhizal symbiosis: Life in the Real world. Mycologist, 19: 102-112.

Utkhede, R.S. and Rahe, J.E. 1983. Interaction of antagonist and pathogens in biological control of onion white rot. Phytopathol., 73: 890-893.

Vaartaja, O. and Morgan, G.A. 1981. Damping off etiology especially in forest nurseries. Phytopathol., 51: 3642.

Vincent, J.M. 1947. Distortion of fungal 
hyphae in the presence of certain inhibitors. Nature, pp 850.

Youins, M.A.M., Heqayan, F.F., Nour-Eldein, M.A. and Shabeb, M.S.A. 2010. Optimization of cultivation of medium and growth conditions of Bacillus subtilis ko strains isolated from sugarcane Molasses. Am-Eursa J. Agric.
Environ. Sci., 7: 31- 37.

Zhao, Z.P. and Kuo, S.C. 1988. Study on hyphal hyperparasitic relationships between Rhizoctonia solani and ectomycorrhizal fungi, p 184-186 in Proceedings of the $5^{\text {th }}$ International Congress of Plant Pathology, Kyoto, Japan.

\section{How to cite this article:}

Waseem Ali Dar, P.A. Sheikh, Baby Summuna and Dar, G.H. 2017. Integrated Disease Management for Root Rot of Himalayan Fir (Abies pindrow) of Western Himalayas of Kashmir -India. Int.J.Curr.Microbiol.App.Sci. 6(5): 273-288. doi: http://dx.doi.org/10.20546/ijcmas.2017.605.032 